\title{
THE PLACE OF TOURISM IN PROMOTIONAL POLICY OF COMMUNES FROM EASTERN POLAND
}

\author{
MIROSŁAW ZALECH \\ Józef Piłsudski University of Physical Education in Warsaw, \\ Faculty of Physical Education and Sport in Biała Podlaska, Department of Management \\ Mailing address: Mirosław Zalech, Faculty of Physical Education and Sport, Department of Management, \\ 2 Akademicka Street, 21-500 Biała Podlaska, tel.: +48 83 3428784, fax: +48 83 3428800, \\ e-mail: miroslaw.zalech@awf-bp.edu.pl
}

\begin{abstract}
Introduction. Promotion in managing local government units constitutes a significant element of communication with various groups of stakeholders, mainly with inhabitants and tourists. This instrument is playing a more and more significant role in the competition for limited resources. Therefore, its significance for territorial marketing is growing. The aim of the study was to identify the directions and range of promotional activity undertaken by communes taking into account their type and financial resources devoted to fulfilling tasks within this area and to define their competitive position. Material and methods. The research was conducted in compliance with the principles of indirect measurement method and data were collected with the use of a questionnaire. Additionally, statistical methods and the author's own method of "assessing promotional position" of local government units were used. The analysis included results obtained from 50 communes from eastern Poland (27 rural, 10 urban and 13 urban-rural communes). Results and conclusions. The research made it possible to identify the competitive position of a commune concerning its promotional activity aimed at inhabitants and tourists, taking into account its territorial range. Additionally, differences in using particular promotional tools were revealed and differences concerning the territorial range and segments which the activities undertaken by the communes are aimed at were noted. The calculations showed the correlation between money spent on promotion by the examined units and their general revenue.
\end{abstract}

Key words: territorial marketing, promotion, expenditures, communes, competitive position, tourism

\section{Introduction}

The processes of decentralisation of public tasks and competences which have taken place in Poland in the last two decades as well as socio-economic changes including the development of telecommunication and information technology [1] increased the competitiveness of new administrative areas [2, 3]. The changing conditions led to the fact that local authorities noticed an opportunity to influence the development of territorial units with financial [4] as well as non-financial tools [5] that they have at their disposal. However, the range of this impact is not unlimited since it occurs on a particular market and it is a relatively autonomous process. Therefore, it is only partially subjected to external influence [6]. The need to impact upon surroundings contributed to the development of territorial marketing as a key tool in developing units. As a consequence, the quality of life is supposed to improve [7]. It seems that the significance of territorial marketing will be growing. It stems from the fact that the areas of services and infrastructure are becoming more and more similar as a result of an increase in integration, removing barriers, giving equal developmental opportunities as well as capital and human mobility [8]. It results in the fact that distinguishing features of communes are becoming more important for attracting inhabitants, tourists and organisations than what they have at their disposal (i.e. resources and functions also possessed by other units). Simultaneously, Hospers [8] highlights a growing importance of soft factors such as active promotional policy that takes into account conditions and the character of a region. Informing about assets is an integral element of building a mar- ket position and plays a crucial role in shaping a positive image of a unit among residents and non-residents. This image is particularly important in tourism. It is an essential factor influencing consumers' decisions regarding travel destinations $[9,10]$.

A decreasing significance of traditional resources (e.g. investment areas, human resources, monuments) possessed by territorial units with a simultaneous increase in the role of unique resources (e.g. properly prepared and more convenient investment areas, highly-qualified human capital, UNESCO sites) constitute one of the factors contributing to a growing importance of marketing communication in terms of functioning and development of territorial units. Other factors include attempting to gain advantage over other regions, reducing disproportions between units with similar qualities as well as meeting informative expectations of particular interest groups.

A huge differentiation and complexity of promotional activities performed by communes in difficult conditions [11], progress in the area of available ways and means of promotion as well as its role in the process of communication served as a basis for conducting research in this field. The aim of this research was to evaluate qualitative and quantitative characteristics of directions and range of promotional activities performed by communes of Podlaskie and Lubelskie Voivodeships taking into consideration selected economic and administrative conditions. An important aspect of this study was to determine competitiveness of the analysed units based on the method that is supposed to help create promotional strategies and facilitate taking decisions in this area. Therefore, the following research hypotheses were tested: 
Table 1. Characteristics of the examined communes $(n=50)$ (data from 2012)

\begin{tabular}{|c|c|c|c|c|c|c|}
\hline Feature & Commune type & $M^{*}$ & SD* & $V^{*}(\%)$ & Min* & $\operatorname{Max}{ }^{*}$ \\
\hline \multirow{3}{*}{ Revenue (thousand) } & urban & 115380.83 & 116825.89 & 101.25 & 13759.83 & 347065.90 \\
\hline & urban-rural & 32102.81 & 13485.52 & 42.01 & 13767.99 & 62173.59 \\
\hline & rural & 17963.70 & 7173.37 & 39.93 & 10278.60 & 46481.31 \\
\hline \multirow{3}{*}{ Expenditures (thousand) } & urban & 112519.63 & 108331.27 & 96.28 & 13210.60 & 313370.52 \\
\hline & urban-rural & 32078.35 & 14075.06 & 43.88 & 13752.59 & 64769.35 \\
\hline & rural & 17570.28 & 6973.07 & 39.69 & 9128.26 & 42402.37 \\
\hline \multirow{3}{*}{ Population (people) } & urban & 30840.30 & 22980.98 & 74.52 & 4545 & 65897 \\
\hline & urban-rural & 11998.00 & 6121.45 & 51.02 & 4908 & 26465 \\
\hline & rural & 5849.41 & 2015.02 & 34.45 & 3220 & 12972 \\
\hline \multirow{3}{*}{ Area $\left(\mathrm{km}^{2}\right)$} & urban & 25.40 & 11.18 & 44.01 & 13 & 49 \\
\hline & urban-rural & 162.85 & 66.14 & 40.61 & 63 & 314 \\
\hline & rural & 129.96 & 57.41 & 44.18 & 81 & 293 \\
\hline
\end{tabular}

* M - arithmetic mean; SD - standard deviation; V - variation coefficient; Min - minimal value; Max - maximal value. Source: author's own work on the basis of data from Local Data Bank (the Main Statistical Office).

- $\quad \mathrm{H}_{1}$ : The frequency of using promotional tools by communes does not differ with regard to the type of the unit and financial resources they allocate to promotion.

- $\mathrm{H}_{2}$ : There is a correlation between financial resources that communes allocate to promotion and their revenue.

- $\mathrm{H}_{3}$ : The level of urbanisation of a territorial unit and its promotion expenditures do not differentiate the range of promotional activities aimed at tourists and inhabitants as well as their spatial range.

- $\mathrm{H}_{4}$ : Integrated evaluation of a promotional position of communes makes it possible to determine mutual relations and define directions and range of their promotional activities.

\section{Material and methods}

The analysis was based on two types of data. The first type included data from primary questionnaire research which was carried out among 90 randomly selected communes from Lubelskie Voivodeship and 90 from Podlaskie Voivodeship. Local government authorities were asked to complete the questionnaire including questions about the frequency and range of promotional activities and expenditures on promotion. The expenditures were divided into 11 categories (increasing by 5000 PLN each). A further analysis included expenditures from particular categories and communes divided into two groups. The first group included those units which spent up to 25000 PLN on promotion $(n=26)$, while the other group included those which spent more money $(n=24)$. The completed questionnaires were returned by 26 rural communes from Lubelskie Voivodeship and 1 from Podlaskie Voivodeship $(\mathrm{n}=27), 2$ urban communes from Podlaskie and 8 from Lubelskie Voivodeship $(\mathrm{n}=10)$ as well as 6 urban-rural communes from Podlaskie and 7 from Lubelskie Voivodeship $(\mathrm{n}=13)$.

The other type of data was obtained from the secondary sources, i.e. from the Local Data Bank of the Main Statistical Office and was used to characterise communes and analyse correlation and regression (tab. 1).

In order to analyse and interpret the collected data, the following statistical methods were applied: arithmetic mean
(M), standard deviation (SD), variability coefficient (V), Pearson's correlation coefficient (r), linear, polynomial and logarithmic regression, Kruskal-Wallis test (H), Mann-Whitney U test (Z).

The market position of communes regarding their promotional activity was defined with the use of the author's own method elaborated on the basis of strategic analyses [12, 13, 14]. The analysis was a pilot study and a suggested solution was called an "integrated assessment of promotional position" (IAPP) since it allowed for defining correlations between the examined local government units taking into account directions and intensity of their promotional activity. The concept of IAPP method was based on the assessment of the communes' involvement in promotion. A matrix was constructed on the basis of three dimensions, i.e. tourists, inhabitants and market. The dimensions included two, three and six market segments respectively. The range of promotional activities in each of the segments was assessed by the representatives of communes on the scale from 1 to 6 (1-sporadic/none, 2 - very small, 3 - small, 4 -average, 5 - big, 6 - very big) (tab. 2).

After the activity in every segment was assessed, the next stage was aimed at defining the total range of activities within each dimension $\left(\mathrm{W}_{1}\right)$ for every examined commune.

$$
\mathrm{W}_{1}=\frac{\sum_{\mathrm{i}=1}^{\mathrm{n}} \mathrm{x}_{\mathrm{i}}}{\sum_{\mathrm{i}=1}^{\mathrm{n}} \mathrm{x}_{\mathrm{i}_{\max }}} \times 100 \%
$$

Then all the $\mathrm{W}_{1}$ values for all the variables (ranges) were used to calculate arithmetic mean. The relations between the activity of communes in particular areas were defined by subtracting arithmetic mean calculated for all the units from $W_{1}$ result for each of the examined units $\left(\mathrm{W}_{2}\right)$.

$$
W_{2}=W_{1}-M
$$

The calculations provided three percentage values including both positive results (higher than the arithmetic mean for the examined communes) and negative results (lower than the 
Table 2. The system of points used to assess the range of promotional activities conducted by the communes

\begin{tabular}{|c|c|c|c|c|c|c|c|c|c|c|c|c|c|c|c|c|c|}
\hline \multirow{3}{*}{ 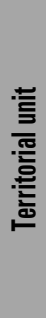 } & \multicolumn{4}{|c|}{ Tourists* } & \multicolumn{5}{|c|}{ Inhabitants* } & \multicolumn{8}{|c|}{ Market ${ }^{*}$} \\
\hline & 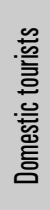 & 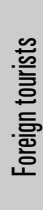 & 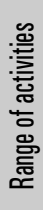 & 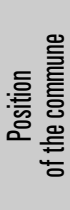 & 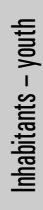 & 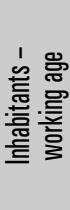 & 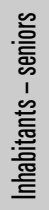 & 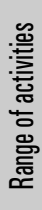 & 墪 & 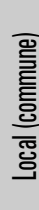 & 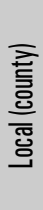 & 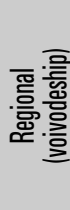 & 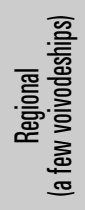 & $\begin{array}{l}\text { 営 } \\
\text { 产 }\end{array}$ & 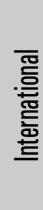 & 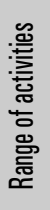 & 宮 \\
\hline & $\mathrm{X}_{1}$ & $\mathrm{X}_{2}$ & $W_{1}$ & $\mathrm{~W}_{2}$ & $X_{3}$ & $X_{4}$ & $X_{5}$ & $\mathrm{~W}_{1}$ & $\mathrm{~W}_{2}$ & $X_{6}$ & $X_{7}$ & $\mathrm{X}_{8}$ & $X_{9}$ & $X_{10}$ & $X_{11}$ & $\mathrm{~W}_{1}$ & $\mathrm{~W}_{2}$ \\
\hline 1 & & & & & & & & & & & & & & & & & \\
\hline 2 & & & & & & & & & & & & & & & & & \\
\hline 3 & & & & & & & & & & & & & & & & & \\
\hline$\ldots$ & & & & & & & & & & & & & & & & & \\
\hline $\mathbf{n}$ & & & & & & & & & & & & & & & & & \\
\hline- & - & - & $M$ & - & - & - & - & $M$ & - & - & - & - & - & - & - & $M$ & - \\
\hline
\end{tabular}

* Each element of the range was assessed on the scale 1 - sporadic/none - 6 - very big. Source: the author's own work.

arithmetic mean for the examined communes). On the matrix one of these values defines the $\mathrm{X}$ axis (inhabitants), the second one defined the $\mathrm{Y}$ axis (tourists), while the third one is presented as the circle volume (market - area).

The aforementioned IAPP analysis made it possible to identify the range and directions of promotional activities and to present the communes' position relative to their competition on the perception map (tab. 3). Additionally, it allowed for drawing conclusions concerning the directions of changes in further promotional activity and enabled local authorities to apply a proper strategy on the basis of their current position.

Table 3. Variants of the position of commune relative to its competition

\begin{tabular}{|c|c|c|c|c|c|c|c|c|}
\hline Variants & 1 & 2 & 3 & 4 & 5 & 6 & 7 & 8 \\
\hline Tourists & + & + & + & + & - & - & - & - \\
\hline Inhabitants & + & + & - & - & + & + & - & - \\
\hline Market & + & - & - & + & - & + & + & - \\
\hline
\end{tabular}

Source: the author's own work.

\section{Results}

From among twenty-nine promotional activities assessed by the representatives of communes, the most common activity was publishing information on the commune's website and publishing it on notice boards. These were the main ways of communication applied by the examined authorities. The third most common activity was advertising with the use of leaflets and brochures. The frequency of these three activities turned out to be the least varied among the examined units. The variability correlations were at the level of $11.35 \%, 18.73 \%$ and $18.86 \%$ respectively. A further analysis indicated that 11 promotional tools were used very often $(\mathrm{M}=4.00$ to 4.99$)$, while 14 tools were used less frequently $(\mathrm{M}=3.00$ to 3.99$)$. The least common tools were sending a newsletter via e-mail and promoting the commune through the participation of its representatives in investment fairs. Local government units varied most as far as newsletter use was concerned ( $\mathrm{V}=55 \%)$. High variability (40-44\%) occurred with regard to the frequency of use of 8 tools (tab. 4). Only three communes took up other promotional activities. One of them used its own LED screen, organised study visits to partner towns and published its own newspaper. The second commune ran a Facebook profile of a town and commune, while the third one published information bulletin.

On the basis of the analyses it may be concluded that the frequency at which the majority of tools is used differs depending on the type of commune and financial resources allocated to promotion (tab. 4). It turned out that the type of commune (i.e. rural, urban, urban-rural) exerted statistically significant influence on the popularity of such promotional activities as publishing information on other websites, publishing maps and guidebooks, preparing materials for the radio, organising/co-organising charity events, advertising on websites other than the communal own website, press interviews by the representatives of the authorities. The multiple comparison test indicated that statistically significant differences $(\mathrm{p}<0.05)$ for these tools existed only between urban and rural communes. On the basis of the mean of ranks it may be concluded that these tools are more often used by urban communes. Significant differences between urban and rural communes as well as between urban and urban-rural communes were revealed with regard to two activities, i.e. issuing promotional films on electronic data storage devices and publishing sponsored articles in the press and on the Internet. Also in this case urban communes were the leaders as far as this type of promotional activity is concerned. Despite the fact that multiple comparison test did not reveal any significant differences, the probability value for the Kruskal-Wallis test revealed that differences in the frequency of publishing information on the communal own website and preparing materials for television depended on the type of commune. The mean of ranks revealed that such activities are most often taken up by urban communes (31.00; 33.45 respectively), less frequently by urban-rural communes $(29.19 ; 28.46)$ and least frequently by rural communes $(21.69 ; 21.13)$ (tab. 5). In the case of 10 tools, financial resources devoted to promotion exerted statistically significant influence on how often they were used (tab. 4). The mean of ranks revealed that the communes which spent more on promotion also had a more active promotional policy. 
Table 4. Type of commune and financial resources devoted to promotion versus the frequency of activities $(n=50)$

\begin{tabular}{|c|c|c|c|c|c|c|}
\hline \multirow[t]{2}{*}{ Tools (activities) } & \multirow[t]{2}{*}{$M^{*}$} & \multirow{2}{*}{$\underset{(\%)}{V}$} & \multicolumn{2}{|c|}{$\begin{array}{c}\text { Type } \\
\text { of a commune }\end{array}$} & \multicolumn{2}{|c|}{$\begin{array}{l}\text { Resources } \\
\text { for promotion }\end{array}$} \\
\hline & & & H & $p$ & 2 & $p$ \\
\hline $\begin{array}{l}\text { Publishing information } \\
\text { on their own website }\end{array}$ & 5.70 & 11.35 & 7.87 & 0.02 & 0.05 & 0.96 \\
\hline $\begin{array}{l}\text { Publishing information } \\
\text { on other websites }\end{array}$ & 3.78 & 31.75 & 7.87 & 0.02 & 1.84 & 0.07 \\
\hline $\begin{array}{l}\text { Sending promotional materials } \\
\text { via e-mail }\end{array}$ & 3.86 & 37.38 & 2.00 & 0.37 & 0.80 & 0.43 \\
\hline Sending a newsletter & 2.62 & 55.01 & 0.17 & 0.92 & $-0,59$ & 0.55 \\
\hline $\begin{array}{l}\text { Participation of a commune } \\
\text { in tourist fairs }\end{array}$ & 3.20 & 41.40 & 3.40 & 0.18 & 2.20 & 0.03 \\
\hline $\begin{array}{l}\text { Participation of a commune } \\
\text { in investment fairs }\end{array}$ & 2.74 & 43.50 & 1.13 & 0.57 & 2.37 & 0.02 \\
\hline $\begin{array}{l}\text { Participation of a commune } \\
\text { in conferences, workshops }\end{array}$ & 4.24 & 27.60 & 1.68 & 0.43 & 2.27 & 0.02 \\
\hline $\begin{array}{l}\text { Publishing information } \\
\text { on notice boards }\end{array}$ & 5.38 & 18.73 & 0.28 & 0.87 & 0.83 & 0.40 \\
\hline Posters & 4.74 & 27.89 & 2.87 & 0.24 & 0.78 & 0.44 \\
\hline $\begin{array}{l}\text { Billboards, citylight adverts, } \\
\text { banners }\end{array}$ & 3.30 & 43.83 & 0.30 & 0.86 & 1.62 & 0.10 \\
\hline Leaflets, brochures & 4.70 & 18.86 & 2.78 & 0.25 & 2.26 & 0.02 \\
\hline Gadgets & 4.12 & 35.58 & 5.40 & 0.07 & 2.04 & 0.04 \\
\hline Publishing books, albums & 3.86 & 35.89 & 4.09 & 0.13 & 2.48 & 0.01 \\
\hline Publishing maps and guidebooks & 4.00 & 33.50 & 15.65 & 0.00 & 2.27 & 0.02 \\
\hline $\begin{array}{l}\text { Promotional films on electronic } \\
\text { data storage devices }\end{array}$ & 3.14 & 43.64 & 11.73 & 0.00 & 2.33 & 0.02 \\
\hline Advertisements in the press & 3.90 & 35.98 & 4.15 & 0.13 & 1.71 & 0.09 \\
\hline Sponsored articles & 3.22 & 43.15 & 8.79 & 0.01 & 2.14 & 0.03 \\
\hline Sports events patronage & 4.74 & 28.85 & 1.75 & 0.42 & 0.17 & 0.86 \\
\hline $\begin{array}{l}\text { Cultural and scientific } \\
\text { events patronage }\end{array}$ & 4.84 & 27.49 & 2.87 & 0.24 & 0.52 & 0.60 \\
\hline $\begin{array}{l}\text { Preparing materials } \\
\text { for the press }\end{array}$ & 4.74 & 21.65 & 3.40 & 0.18 & 0.58 & 0.56 \\
\hline $\begin{array}{l}\text { Preparing materials } \\
\text { for the radio }\end{array}$ & 3.58 & 41.50 & 10.76 & 0.00 & 1.55 & 0.12 \\
\hline $\begin{array}{l}\text { Preparing materials } \\
\text { for television }\end{array}$ & 3.18 & 40.53 & 6.38 & 0.04 & 2.30 & 0.02 \\
\hline $\begin{array}{l}\text { Organising/co-organising } \\
\text { competitions }\end{array}$ & 4.46 & 25.31 & 3.12 & 0.21 & 1.15 & 0.25 \\
\hline $\begin{array}{l}\text { Sponsoring sports clubs, } \\
\text { athletes }\end{array}$ & 4.74 & 28.21 & 0.88 & 0.64 & -0.05 & 0.96 \\
\hline $\begin{array}{l}\text { Organising/co-organising } \\
\text { charity events }\end{array}$ & 3.40 & 39.86 & 6.62 & 0.04 & 1.72 & 0.09 \\
\hline $\begin{array}{l}\text { Sending promotional materials } \\
\text { via traditional mail }\end{array}$ & 3.42 & 36.46 & 2.18 & 0.34 & -1.44 & 0.15 \\
\hline $\begin{array}{l}\text { Online advertisement on websites } \\
\text { other than the commune's own website }\end{array}$ & 3.14 & 41.70 & 8.67 & 0.01 & 1.81 & 0.07 \\
\hline $\begin{array}{l}\text { Sponsoring cultural, } \\
\text { scientific events }\end{array}$ & 3.96 & 38.16 & 1.68 & 0.43 & 1.24 & 0.21 \\
\hline Press interviews & 4.16 & 27.63 & 7.72 & 0.02 & 0.65 & 0.52 \\
\hline
\end{tabular}

* Arithmetic mean of assessment on 1-6 scale where 1 - sporadical/none, 2 - very small, 3 - small, 4 - average, 5 - big, 6 - very big.

Source: the author's own work.
Table 5. Multiple comparison value " $z$ " for statistically significant differences (Kruskal-Wallis test) of the frequency of promotional activities according to the types of communes

\begin{tabular}{|l|c|c|c|}
\hline \multicolumn{1}{|c|}{ Tools (activities) } & UR-U* & UR-R & U-R* \\
\hline Publishing information on their own website & 0.295 & 1.526 & 1.726 \\
\hline Publishing information on other websites & 1.765 & 0.713 & $2.655^{* *}$ \\
\hline Publishing maps and guidebooks & 1.834 & 1.845 & $3.767^{* *}$ \\
\hline Promotional films on electronic data storage devices & $2.746^{* * *}$ & 0.124 & $3.233^{* *}$ \\
\hline Sponsored articles & $2.438^{* *}$ & 0.004 & $2.767^{* *}$ \\
\hline Preparing materials for the radio & 1.073 & 1.914 & $2.965^{* *}$ \\
\hline Preparing materials for television & 0.814 & 1.490 & 2.283 \\
\hline Organising/co-organising charity events & 1.680 & 0.587 & $2.444^{* *}$ \\
\hline $\begin{array}{l}\text { Online advertisement on websites other } \\
\text { than the communje's own website }\end{array}$ & 2.274 & 0.224 & $2.788^{* *}$ \\
\hline Press interviews & 2.019 & 0.280 & $2.550^{* *}$ \\
\hline
\end{tabular}

* Type of commune: UR - urban-rural, R - rural, U - urban; * $\mathrm{p}<0.05$. Source: the author's own work.

The value of linear correlation coefficient $(r=0.451)$ between revenues and expenditures on promotion showed statistically significant positive correlation $(\mathrm{p}=0.001)$. The analysis of the spread graph (fig. 1) revealed standing out values which related to three county towns. Their revenues were much higher than those of the remaining communes and their expenditures were among the highest similarly to the communes with much lower revenues. Because of this result and the fact that the correlation coefficient is highly influenced by border values [15] another analysis without these units was performed.

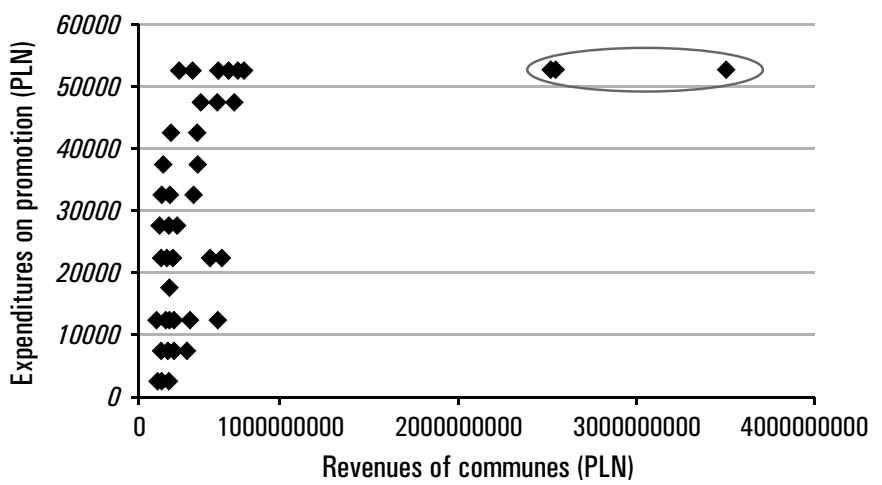

Note: the figure includes border values.

Source: the author's own work.

Figure 1. The revenues of communes and their expenditures on promotion $(n=50)$

The value of the linear correlation coefficient for the analysed 47 communes was at the level of $r=0.617$ and was significant at the level of $p=0.000$. Despite such high correlation, after a visual assessment of the spread of data, it was impossible to confirm their linear character (fig. 2). Therefore, in order to prepare a quantitative description of the correlations, three regression models were tested. The correlation defining the level of the variable ' $y$ ' revealed that the best matched regression curve was not a linear function $\left(\mathrm{R}^{2}=0.380\right)$, or a polynomial function $\left(R^{2}=0.397\right)$, but a logarithmic function $\left(R^{2}=0.405\right)$ for which regression equation was as follows:

$y=22308 \ln x-351268$ 
where:

$\mathrm{y}$-expenditures on promotion in PLN

$\mathrm{x}$-revenues of communes in PLN

The obtained value of the coefficient of determination allowed for indicating that $40.5 \%$ of the variability of the amounts spent on promotion may be explained by the influence exerted by the revenues of communes. The correlations are presented in figure 2.

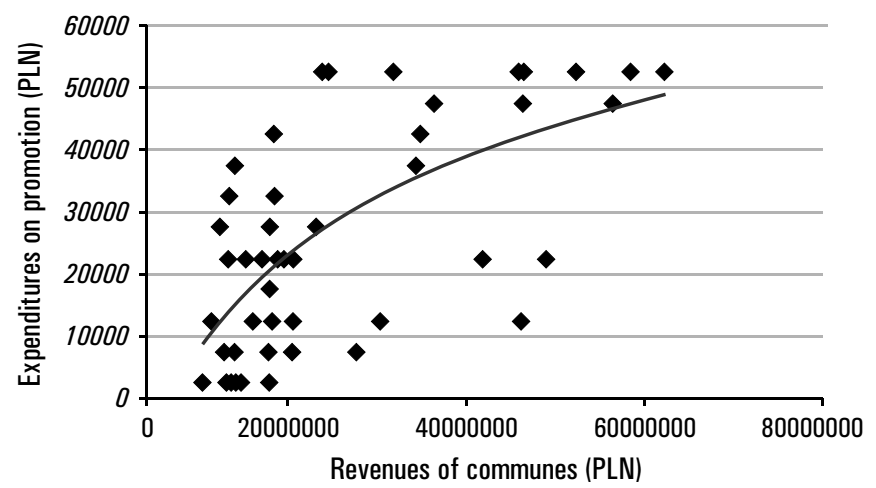

Source: the author's own work.

Figure 2. Revenues versus expenditures allocated to promotion by communes - excluding county towns $(n=47)$

In a further analysis the correlation between revenues of the commune per capita and expenditures on promotion were assessed. It turned out that there existed no correlation between these variables $(\mathrm{r}=-0.0812, \mathrm{p}=0.587)$. The spread graph confirmed that there was neither linear nor curvilinear correlation between the examined variables (fig. 3). Therefore, it may be concluded that the amount spent on promotion does not depend on the increase or decrease in revenue per capita.

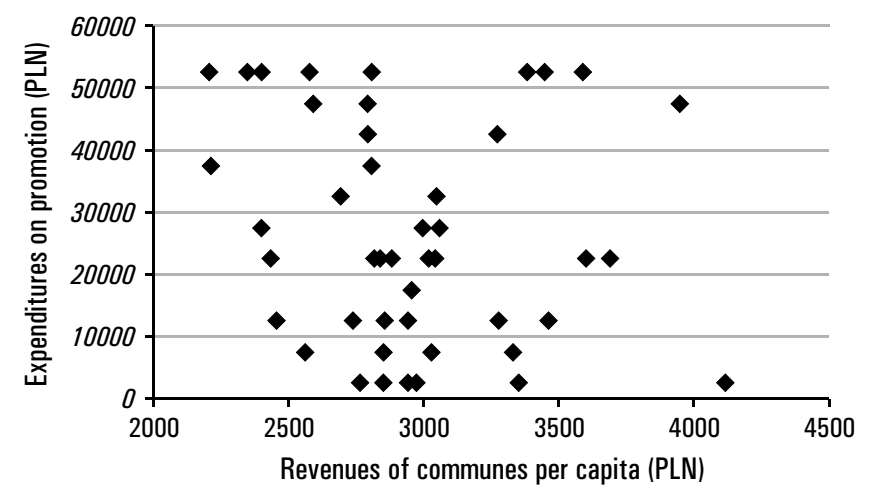

Source: the author's own work.

Figure 3. Revenues per capita versus communes' expenditures on promotion $(\mathrm{n}=47)$

Promotional activity of the communes differed depending on the type of unit in four territorial segments and one target group segment (target group of the activities). The calculated values of Kruskal-Wallis test and their respective significance level $(p<0.05)$ revealed that there are differences between urban, rural and urban-rural communes concerning the range of promotional activity on the local (county), regional (voivodeship), regional (a few voivodeships) and international market is not at the same level. Such difference was also revealed with regard to promotion aimed at working-age inhabitants (tab. 6).

The multiple comparison test provided an answer to the question which type of communes conducts promotional activity in a significantly $(\mathrm{p}<0.05)$ broader range and which in a significantly smaller range. There occurred only one statistically significant difference between urban and rural communes relating to three segments (both regional ones and an international one). On the basis of a mean rank it may be concluded that urban communes act in these segments on a larger scale. There were no differences between the types of communes relating to their activity in the county aimed at working-age inhabitants. However, the means of ranks allowed for concluding that this scale was biggest in urban $(34.15 ; 32.30$ respectively), smaller in urban-rural (27.50; 29.69), and the smallest in rural communes (21.33; 20.96) (tab. 7).

In order to get to know whether the amount of expenditures devoted to promotion by communes does not differentiate the scale of the promotional activity aimed at particular segments in this area, a non-parametric Mann-Whitney U test was used. The obtained values turned out to differentiate significantly the scale of the activity in the county, voivodeship, a few voivodeships and the country as well as the activity aimed at domestic tourists depending on the expenditures. More considerable promotional activity in these areas was noted in those communes which spent more than 25000 PLN per year $(n=24)$.

Table 6. The type of commune and financial resources versus the range of promotional activities in particular markets $(n=50)$

\begin{tabular}{|l|c|c|c|c|c|c|}
\hline \multirow{2}{*}{\multicolumn{1}{c|}{ Market (range) }} & \multirow{2}{*}{$\mathbf{M}^{*}$} & \multirow{2}{*}{$\begin{array}{c}\text { V } \\
\text { l\%) }\end{array}$} & \multicolumn{2}{c|}{$\begin{array}{c}\text { Type } \\
\text { of commune }\end{array}$} & \multicolumn{2}{c|}{$\begin{array}{c}\text { Resources } \\
\text { for promotion }\end{array}$} \\
\cline { 5 - 8 } & & & $\mathbf{H}$ & $\mathbf{p}$ & $\mathbf{Z}$ & $\mathbf{p}$ \\
\hline Local (commune) & 5.16 & 22.27 & 2.26 & 0.32 & 1.73 & 0.08 \\
\hline Local (county) & 4.56 & 26.64 & 6.70 & 0.04 & 2.57 & 0.01 \\
\hline Regional (voivodeship) & 3.78 & 33.07 & 7.29 & 0.03 & 3.21 & 0.00 \\
\hline Regional (a few voivodeships) & 2.96 & 41.49 & 10.56 & 0.01 & 3.17 & 0.00 \\
\hline National & 2.68 & 41.59 & 3.99 & 0.14 & 3.31 & 0.00 \\
\hline International & 2.30 & 43.26 & 8.58 & 0.01 & 1.92 & 0.05 \\
\hline Inhabitants - the youth & 4.90 & 18.55 & 3.38 & 0.18 & 0.74 & 0.46 \\
\hline Inhabitants - working age & 4.92 & 15.28 & 6.93 & 0.03 & 1.52 & 0.13 \\
\hline Inhabitants - seniors & 4.44 & 22.37 & 2.46 & 0.29 & 1.90 & 0.06 \\
\hline Domestic tourists & 3.98 & 28.93 & 5.02 & 0.08 & 2.00 & 0.04 \\
\hline Foreign tourists & 2.90 & 41.36 & 4.85 & 0.09 & 1.88 & 0.06 \\
\hline
\end{tabular}

* Arithmetic mean of assessment on 1-6 scale where 1-sporadical/none,

2 - very small, 3 - small, 4 - average, 5 - big, 6 - very big.

Source: the author's own work.

Table 7. Multiple comparison value "z" for statistically significant differences (Kruskal-Wallis test) in the range of promotional activities according to types of communes

\begin{tabular}{|l|c|c|c|}
\hline \multicolumn{1}{|c|}{ Market (range) } & UR-U* & UR-R $^{*}$ & U.R $^{*}$ \\
\hline Local (county) & 1.085 & 1.253 & 2.375 \\
\hline Regional (voivodeship) & 1.245 & 1.182 & $2.493^{* *}$ \\
\hline Regional (a few voivodeships) & 1.260 & 1.739 & $3.017^{* *}$ \\
\hline International & 1.179 & 1.456 & $2.667^{* *}$ \\
\hline Inhabitants - working age & 0.425 & 1.774 & 2.101 \\
\hline
\end{tabular}

* Type of commune: UR - urban-rural, R - rural, U - urban; * ${ }^{*}<0.05$. Source: the author's own work.

The process of positioning the communes according to the assumptions of the IAPP method made it possible to mark out 
on the matrix the position of every commune relative to the remaining ones. The criteria of determining the position were the range of the promotional activity aimed at tourists and inhabitants as well as the territorial range. In order to clarify the results, the data were presented in two figures, the first of which (fig. 4) included urban and urban-rural communes and the second one (fig. 5) included rural communes. The volume of the circle shows the scale of the activities conducted by the particular communes, while the $\mathrm{X}$ axis shows these activities which were aimed at inhabitants, and the Y axis presents these aimed at tourists (fig. 4 and 5).

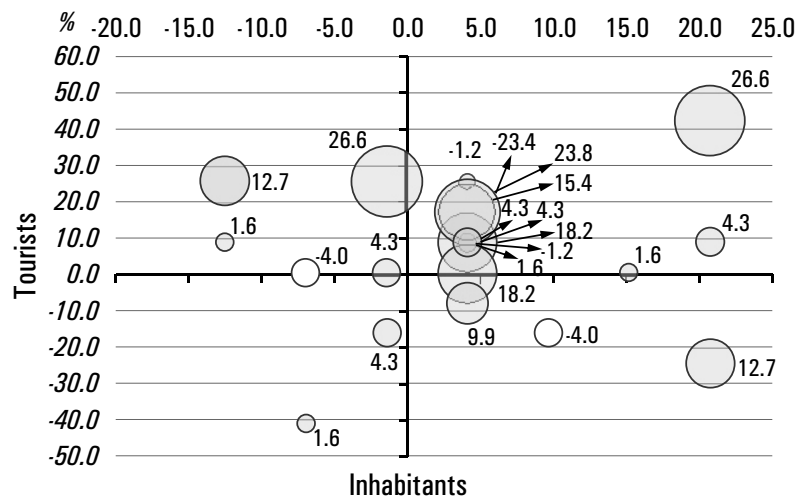

Source: the author's own work.

Figure 4. Directions and range of promotional activities in urban and urban-rural communes $(\mathrm{n}=23)$

The values in three dimensions marked in the graph showed the position of every commune and allowed for their interpretation according to the variants defined in table 2 . It turned out that the biggest number of units, i.e. 16 performed many activities in three dimensions (variant 1), while 8 communes conducted a low number of activities in the three dimensions (variant 8). Six of the examined communes aimed their main activities at tourists and inhabitants but they did it on a limited scale (variant 2). Only 3 of the examined communes were characterised by an opposite variant (variant 7). Five communes focused mainly on the promotion aimed at tourists only, while they did not pay a lot of attention to the other two dimensions (variant 3). The situation in which communes focused mainly on shaping relations with inhabitants on a large scale while conducted limited activity aimed at tourists was noted in four units (variant 6). For seven communes tourists and scope of the market were very significant (variant 4), while only one commune focused its main promotional activity on the inhabitants only and worked on a limited scale and conducted limited activity aimed at tourists (variant 5) (fig. 4 and 5).

Taking into account the type of local government units in the analysis, it must be noted that the most common variant of the position of the communes according to their promotional activity among urban communes was variant 1 (6 units), among urban-rural communes - variant 2 (4 units) and among rural ones - variant 8 ( 8 units). None of the units from among the first type of communes conducted activity according to variant 5 and 8 , none of the units from among the second type according to variant 3 and 8 , none from the third type according to variant 5 (fig. 4 and 5).

The range of promotional activities aimed at tourists, inhabitants and various markets is bigger than the arithmetic mean (urban communes $-80.0 \%, 70.0 \%$ and $90.0 \%$ respectively; urban-rural $76.9 \%, 69.2 \%$ and $61.5 \%$; rural $-59.3 \%, 40.7 \%$ and $48.1 \%)$.

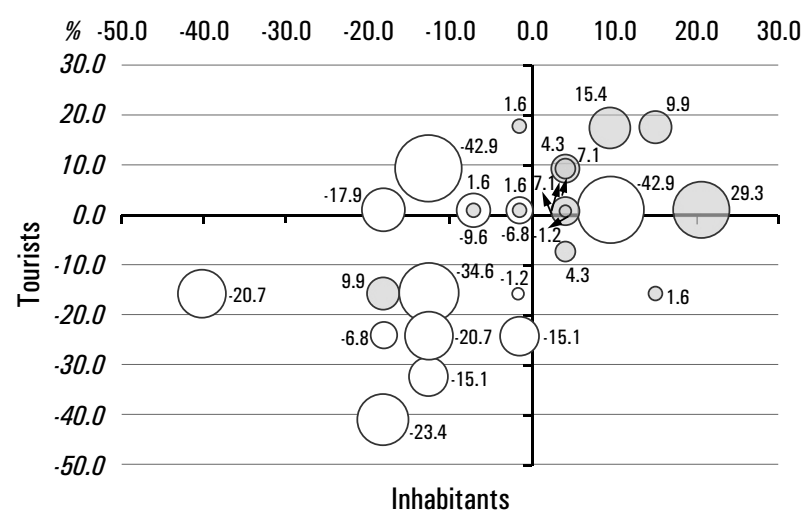

Source: the author's own work.

Figure 5. Directions and range of promotional activities in rural communes $(n=27)$

\section{Discussion}

On the basis of the research it may be concluded that activities most commonly implemented in promotion are those regarded as traditional. It is noticeable that they are divided into two groups. The first one consists of tools used to communicate with inhabitants. Their application is not expensive because they include publishing information on notice boards, posters as well as sports, cultural and scientific events patronage and preparing materials for the press. The other group includes those forms which are mainly used to promote a brand, create an image and to present an offer of a commune to potential and current tourists, i.e. leaflets, brochures, maps and guidebooks. Apart from traditional methods, communes often rely on one of the Internet activities, such as publishing and updating information on their own website. Unfortunately, their engagement in social media activities is either very low or non-existent. Although this type of communication does not require considerable financial resources and it is very fast, accessible, widespread and interactive, it is still unknown to communes. Another form that communes often used was sponsoring sports clubs and athletes. This tool helps to combine promotion of units with supporting their inhabitants participating in physical activity. Both types of activity form communes' own objectives [16]. The findings also revealed considerable differences between communes concerning the frequency of performing the majority of promotional activities. It may stem from priorities that authorities set in terms of promotion as well as differentiated human resources and qualifications of their personnel. It should be assumed that it also depends upon such factors as the type of a tool (activity), level of difficulty, price and necessary commitment. Due to a financial deficit, authorities often focus on solutions which do not generate big costs [17].

The obtained research results made it possible to conclude that depending on the type the communes differed in the frequency of performing five activities, while in the case of four communes these differences resulted from their promotion expenditures. For these activities there is a statistically significant basis for rejecting $\mathrm{H}_{1}$. It shows that if a commune is more urbanised and it spends more money on promotion, these promotional tools are used more frequently. The aforementioned criteria do not differentiate the frequency of performing other activities in a statistically significant manner, so they do not contradict the first hypothesis $\left(\mathrm{H}_{1}\right)$. This differentiation may stem from the fact that rural communes seldom undertake promotional activities, Internet tools are rarely implemented and marketing expenditures are low [18]. 
The analysis revealed no correlations between the amount of money spent on promotion and revenue per capita in a commune. However, linear correlation was found between the revenue of a commune and overall promotion expenditures. Despite the existence of significant linear correlation, though, data spread graph did not show clearly the linear form of regression function. Therefore, three models of regression were tested. The logarithmic model turned out to be the best matched. Thus, based on the gathered data it may be concluded that promotion expenditures do not depend on revenue per capita but on overall revenue of the communes $\left(\mathrm{H}_{2}\right)$. It means that the amount of money communes spend on promotion is not determined by their wealth but by financial resources they have at their disposal. This correlation indicates that only slightly over $40 \%$ of promotion expenditure variability depends on overall revenue of the communes. The remaining part is conditioned by other factors such as objectives of promotion policy, type of activities as well as recipients of activities [19]. However, we ought to bear in mind that differences between correlations of determination in three tested models (linear, polynomial, logarithmic) turned out to be small. Therefore, further research is needed in this field.

Communes compared according to type differed in their promotional activity in 5 out of 11 markets. Also, the same number of markets differed in the range of promotion in terms of financial resources spent on it by communes. It bears out the assumption only partially $\left(\mathrm{H}_{3}\right)$. The differentiation in the range of promotional activities carried out by local governments concerns territorial range mainly. The results of the analyses also revealed that the type of a commune is the factor that differentiates the scale of activities aimed at working-age inhabitants, while promotion expenditures differentiate activities directed at domestic tourists. The findings indicate indirectly that the range of promotion policy may stem not only from the type and wealth of a commune but also from individual features of units, priorities and their importance to authorities [20] as well as from an implemented system of unit management, its efficiency or deficiency [21].

An integrated method of evaluating promotional position made it possible to create a 3-D perception map that showed the location of the examined communes relative to one another. It was achieved through identifying correlations between the range of promotional activities aimed at tourists and those directed at inhabitants taking into account their territorial range. The mapping of those correlations on the matrix helps to obtain a lot of information useful in preparing promotional strategies. These strategies may include changing or enhancing the course of previous activities and their range, continuing to realise current policies as well as following competition. The positioning of the communes based on the presented method and the findings are in line with the assumptions made in the fourth hypothesis $\left(\mathrm{H}_{4}\right)$. In the context of the analyses it should be noted that comparing units makes it possible to show their global status and to highlight differences, developmental disproportions and competitive strength in social and economic dimensions as well as to define their attractiveness for various interest groups $[22,23,24]$.

At present a significant number of local governments use strategic planning in order to set long-term directions and priorities, help take decisions and prepare strategies and programmes of development. As it is noted by the authorities, benefits from strategic planning are significantly higher than the costs of implementing these plans [25]. However, it must be remembered that communes are not alienated. Therefore, in order to create a strategy it is necessary not only to analyse their position relative to the competition but also to identify financial resources as well as these elements which are either perma- nently connected with a unit or whose change would require considerable resources. Individual features of a unit resulting from specific factors (e.g. history, culture, anthropogenic and natural values) are also significant [26].

\section{Acknowledgements}

The research was accomplished within the framework of research project of the Faculty of Physical Education and Sport in Biała Podlaska, Józef Piłsudski University of Physical Education in Warsaw - MN. I/1 - financed by the Ministry of Science and Higher Education realised in the years 2011-2012.

\section{Literature}

1. Piątkowski M. (2004). The influence of information technologies on economic growth and work efficiency in Poland in the years 1995-2000. Gospodarka Narodowa 1-2, 37-52. [in Polish]

2. Adamowicz M. (2008). Competitiveness of territorial units on a local scale. Roczniki Naukowe Stowarzyszenia Ekonomistów Rolnictwa i Agrobiznesu 10(2), 7-13. [in Polish]

3. Bareja E. (2011). Significance of asset-related expenditures in creating competitiveness of towns and cities. Folia Pomeranae Universitatis Technologiae Stetinensis. Oeconomica 291(65), 7-16. [in Polish]

4. Kożuch A., Kołoszko-Chomentowska Z. (2003). The commune budget as a tool of local development. In M. Adamowicz (Ed.), Strategies of local development. Volume II. Instrumentals aspects (pp. 177-187). Warszawa: Wydawnictwo SGGW. [in Polish]

5. Chomiak-Orsa I., Flieger M. (2012). Stimulating local economic development. An attempt at evaluating the effectiveness of extra-budgetary activities of communes. Zeszyty Naukowe Wyższej Szkoły Oficerskiej Wojsk Lądowych 4, 177 185. [in Polish]

6. Adamowicz M. (2003). Shaping local development. W M. Adamowicz (Ed.), Strategies of local development. Volume II. Instrumentals aspects (pp. 11-22). Warszawa: Wydawnictwo SGGW. [in Polish]

7. Augustyn A. (2011). Territorial marketing as a factor in local development. Optimum. Studia Ekonomiczne 5(53), 99-113.

8. Hospers G.J. (2004). Place marketing in Europe. The branding of the Oresund Region. Intereconomics. Review of European Economic Policy 39(5), 271-279.

9. Prayag G. (2009). Tourists' evaluations of destination image, satisfaction, and future behavioral intentions - the case of Mauritius. Journal of Travel \& Tourism Marketing 26, 836-853.

10. Bigne J., Sanchez M., Sanchez J. (2001). Tourism image, evaluation variables and after purchase behavior: Inter-relationships. Tourism Management 22(6), 607-616.

11. Kotler P., Caslione J.A. (2009). Chaotics: the business of managing and marketing in the age of turbulence. New York: AMACOM.

12. Gierszewska G., Romanowska M. (1998). Strategic analysis of a company. Warszawa: PWE. [in Polish]

13. Fleisher C., Bensoussan B. (2002). Strategic and competitive analysis: methods and techniques for analyzing business competition. USA: Prentice Hall.

14. Lisiński M. (2004). Methods of strategic planning. Warszawa: PWE. [in Polish]

15. Stanisz A. (2006). Intelligible statistics course based on STATISTICA PL programme and examples from medicine. Volume 1. Basic statistics. Kraków: StatSoft Polska. [in Polish] 
16. Act of $8^{\text {th }}$ March 1990 on communal authority (Official Journal of Laws 1990 No. 16 item 95 with later amendments). [in Polish]

17. Dziekański P. (2012). Promotion as an element of communication between local authority unit and surroundings. Acta Scientifica Academiae Ostroviensis. Sectio A 1, 27-52. [in Polish]

18. Guzal-Dec D., Zwolińska-Ligaj M. (2008). Promotional activities of communal offices as exemplified by selected rural communes of Lubelskie Voivodeship. Rozprawy Naukowe Państwowa Wyższa Szkoła Zawodowa im. Papieża Jana Pawła II w Białej Podlaskiej 2, 179-194. [in Polish]

19. Rawski M. (2011). Selected difficulties regarding the realisation of a functional aspect in territorial marketing. Zeszyty Naukowe Uniwersytetu Szczecińskiego nr 596, Ekonomiczne Problemy Usług 56, 61-73. [in Polish]

20. Marczak M. (2008). Analysis of tourism promotion in Pomerania communes. Zeszyty Naukowe Politechniki Rzeszowskiej 249, Zarzqdzanie i Marketing 13, 245-254. [in Polish]

21. Kołomycew A. (2010). Promotion in the activities of public administration (as exemplified by the communes of Tarnobrzeg county). Polityka i Społeczeństwo 7, 90-99. [in Polish]
22. Hu R., Blakely E.J., Zhou Y. (2013). Benchmarking the competitiveness of Australian global cities: Sydney and Melbourne in the global context. Urban Policy and Research 31(4), 1-18.

23. Huggins R. (2003). Creating a UK competitiveness index: regional and local benchmarking. Regional Studies 37(1), 89-96.

24. Szromnik A. (2002). Methodological problems of shaping marketing strategy of a spatial and administrative unit. Samorzad Terytorialny 7-8, 62-78. [in Polish].

25. Poister T.H., Streib G. (2005). Elements of strategic planning and management in municipal government: status after two decades. Public Administration Review 65(1), 45-56.

26. Jabłońska W. (2010). Urban promotion as the main function of territorial marketing. Zeszyty Naukowe Wyższej Szkoły Ekonomii i Informatyki 6, 71-86. [in Polish]

Submitted: December 2, 2013

Accepted:January 7, 2014 